\title{
ANALISIS EFEKTIVITAS PEMUNGUTAN PAJAK PENJUALAN ATAS BARANG MEWAH TERHADAP PENERIMAAN PAJAK DI KPP PRATAMA MANADO
}

\author{
Oleh: \\ Fenny Fega Stela Sorongan ${ }^{1}$ \\ Lintje Kalangi ${ }^{2}$ \\ Steven Tangkuman ${ }^{3}$
}

\author{
Fakultas Ekonomi dan Bisnis, Jurusan Akuntansi \\ Universitas Sam Ratulangi Manado \\ Email : sorongan_fenny@yahoo.com
}

\begin{abstract}
Abstrak: Sejalan dengan perkembangan ekonomi, teknologi informasi, sosial, politik, disadari bahwa sistem pelaksanaan perpajakan di Indonesia membutuhkan suatu ketentuan dan tata cara yang baik. Pajak Penjualan Atas Barang Mewah merupakan jenis pajak yang sangat potensial dalam penerimaan Daerah maupun untuk Negara. Objek penelitian ini diambil pada Kantor Pelayanan Pajak Pratama Manado,untuk mengetahui kinerja dari tahun 2011-2014 efektif atau kurang efektif. Hal ini yang dapat dianlisa terhadap kinerja kantor Pelayanan Pajak Pratama Manado.Tujuan dari penelitian ini adalah untuk mengetahui efektivitas pemungutan Pajak Penjualan atas Barang Mewah terhadap penerimaan.Data yang telah diolah kemudian dianalisis dengan menggunakan metode penelitian analisis deskriptif kualitatif. Hasil penelitian menujukan bahwa tatacara pembayaran dalam hal pemungutan kepada wajib pajak sudah benar sesuai dengan peraturan Undang- Undang yang berlaku. Begitu juga dengan tingkat kinerja Kantor Pelayanan Pajak Partama Manado Efektif, bahkan ada beberapa tahun sangat efektif. Namun kinerja harus tetap ditingkatkan karena target yang diberikan ada perubahan penurunan pada salah satu tahun, walaupun realisasinya tercapai. Yang seharusnya setiap tahun target meningkat begitu juga dengan realisasinya. Dengan demikian pencapaian kinerja KPP Pratama Manado efektif.
\end{abstract}

Kata Kunci : Sistem Pemungutan, PPnBM, Efektivitas

\begin{abstract}
: along with economic development, information technology, social, political, realized that the implementation of the taxation system in Indonesia requires a provision and good manners. Sales Tax on Luxury Goods is a type of tax potential in the reception area is well to state. The object of this study was taken at the Tax Office Primary Manado, to determine the performance of the 2011-2014 effective or less effective. It can be in anlisa on performance Pratama Tax Service office Manado. The purpose of this study was to determine the effectiveness of the collection of Sales Tax on Luxury Goods on receipt. Data that has been processed and analyzed using qualitative descriptive analysis research method. The results of the study addressed that the payment procedure in terms of voting to taxpayer is right in accordance with the law. So level of performance Partama Manado Tax Office Effectively, there are even a few years of very effective . However, the performance should be increased for a given target is no change the decrease in one year, although its realization is achieved. That should have been the target increases each year as well as its realization. Thereby acchieving Performance KPP Pratama Manado can be said effective.
\end{abstract}

Keywords : self assesment, PPnBM, Effective 


\section{PENDAHULUAN}

\section{Latar Belakang}

Sejalan dengan perkembangan ekonomi, teknologi informasi, sosial, politik, disadari bahwa sistem pelaksanaan perpajakan di Indonesia membutuhkan suatu ketentuan dan tata cara yang sesuai dengan tingkat kehidupan masyarakat Indonesia baik dari segi kegotong-royongan nasional maupun dari laju pembangunan nasional yang telah dicapai.

Dengan kehidupan masyarakat yang semakin dinamis ketentuan dan tata cara perpajakan pun telah mengalami perubahan. Hal ini diharapkan bahwa lebih memberikan keadilan, meningkatkan pelayanan kepada Wajib Pajak, meningkatkan kepastian dan penegakan hukum, sehingga tidak ada lagi masyarakat indonesia yang tidak paham akan sistem perpajakan.

Pajak Penjualan atas Barang Mewah (PPnBM) merupakan pajak yang dikenakan pada barang atau produk yang dipandang bukan sebagai barang kebutuhan pokok, dan dikonsumsi oleh masyarakat tertentu yang pada umumnya merupakan masyarakat berpenghasilan tinggi, juga barang yang dibeli untuk menunjukkan status, atau jika dikonsumsi dinilai dapat merusak kesehatan dan moral masyarakat Indonesia. Pajak Penjualan Atas barang Mewah merupakan jenis pajak yang merupakan satu paket dalam Undang-undang Pajak Pertambahan Nilai. Namun demikian, mekanisme pengenaan PPnBM ini sedikit berbeda dengan Pajak Pertambahan Nilai Pengenaan PPnBM sebagaimana dimaksud pada ayat (1) adalah berdasarkan Kelompok Barang Kena Pajak yang Tergolong Mewah yang berupa Kendaraan Bermotor sebagaimana dimaksud dalam Peraturan Pemerintah Nomor 41 Tahun 2013 tentang Barang Kena Pajak yang Tergolong Mewah Berupa Kendaraan Bermotor yang Dikenai Pajak Penjualan atas Barang Mewah sebagaimana telah diubah dengan Peraturan Pemerintah Nomor 22 Tahun 2014. Berdasarkan Pasal 5 Ayat (1) Undang-undang PPN, Pajak Penjualan Atas Barang Mewah dikenakan terhadap (1) penyerahan Barang Kena Pajak Yang Tergolong Mewah yang dilakukan oleh Pengusaha yang menghasilkan Barang Kena Pajak Yang Tergolong Mewah di dalam Daerah Pabean dalam kegiatan usaha atau pekerjaannya (2) impor Barang Kena Pajak Yang Tergolong Mewah. Dengan demikian, Pajak Penjualan Atas barang Mewah hanya dikenakan pada saat penyerahan BKP Mewah oleh pabrikan (pengusaha yang menghasilkan) dan pada saat impor BKP Mewah.

Aturan yang masuk ke dalam paket kebijakan ekonomi pemerintah jilid I ini sudah ketiga kalinya dikatakan akan berlaku. Awalnya pada November 2013, lalu Januari 2014, dan sekarang April 2014. Dari sisi volume dan nilai, impor mobil mewah memang tidak terlalu besar, sehinggga pengurangan impor hanya sedikit. Jadi, pengaruh dalam perbaikan defisit transaksi berjalan (DTB) sangat sedikit, begitu juga dengan sisi penerimaan.Namun, pemerintah tetap harus bersikap untuk mengurangi impor barang konsumsi untuk memperbaiki postur anggaran dan kinerja fiskal yang sehat dan berkesinambungan. Hanya saja, pemerintah harus maklum, meskipun pajak untuk kendaraan mewah (PPnBM) sudah dinaikkan, namun golongan masyarakat kaya Indonesia cenderung tetap akan membeli kendaraan mewah tersebut. Hal ini karena sifat harga kendaraan mewah adalah inelastis. Artinya, pemerintah mau menaikkan pajaknya sebesar apapun, namun mereka tetap akan membeli mobil bukan karena butuh, tapi karena kesenangan dan gengsi untuk status sosial.

Dalam penelitian ini, penulis mencoba untuk membahas secara rinci mengenai pengenaan PPN dan efektivitas PPnBM terhadap Kendaraan Bermotor khusunya pada kendaraan roda empat dengan tetap mengacu pada ketentuan-ketentuan yang berlaku. Untuk mengetahui seberapa efektiv peraturan pemerintah mengenai pembayaran pajak PPnBM di kota Manado, apakah sudah berjalan sesuai dengan peraturan pemrintah yang berlaku maka penulis menetapkan judul bagi penulisan skripsinya yaitu : "Efektivitas Pemungutan Pajak Penjualan Atas Barang MewahTerhadap Penerimaan Pajak di KPP Pratama Manado". 


\section{Tujuan Penelitian}

Tujuan yang ingin dicapai dalam penelitian ini yaitu untuk mengetahui bagaimana efektivitas pemungutan PPnBM terhadap penerimaan pajak di KPP Pratama Manado.

\section{TINJAUAN PUSTAKA}

\section{Pengertian Pajak}

Prof. Dr. Rochmat Soemitro, SH dalam bukunya Mardiasmo (2011 : 1) : "Pajak adalah iuran rakyat kepada kas Negara berdasarkan Undang-undang (yang dapat dipaksakan) dengan tiada mendapat jasa timbal (kontra Prestasi) yang langsung dapat ditunjukkan dan yang digunakan untuk membayar pengeluaran umum.

\section{Fungsi Pajak}

Dari pengertian pajak telah disampaikan sub bab diatas, secara tertulis dan praktisi bahwa pajak memiliki berbagai fungsi dalam kehidupan negara dan masyarakat (Mardiasmo, $2011: 1$ ), yaitu :

a. Fungsi Budgetair

b. Fungsi Regulerend (Mengatur)

c. Fungsi Distribusi

d. Fungsi Demokrasi

\section{Analisis Efektivitas}

Menurut Mardiasmo (2009:134)Analisis efektivitas adalah pengukuran dalam arti tercapainya sasaran atau tujuan yang telah ditentukan sebelumnya. Sedangkan menurut Hidayat $(1990 ; 67)$ efektifitas adalah suatu ukuran yang menyatakan seberapa jauh target yang telah dicapai, semakin tinggi atau besar target yang dicapai maka semakin tinggi tingkat efektifitasnya.Maka bila sasaran atau tujuan telah tercapai sesuai dengan yang telah direncanakan sebelumnya, hal ini dikatakan efektif. Jadi apabila tujuan atau sasaran tidak sesuai dengan yang ditentukan, maka pekerjaan itu kurang efektif. Dapat dinyatakan bahwa efektifitas merupakan kemampuan optimum pencapaian target yang telah direncanakan baik dari segi hasil suatu usaha maupun ketepatan waktunya.

\section{Sistem Pemungutan Pajak}

Dalam pemungutan pajak dikenal beberapa sistem pemungutan pajak yaitu :

\section{a. Official Assessment System}

Merupakan sistem pemungutan pajak yang memberikan kewenangan aparatur perpajakan untuk menentukan sendiri jumlah pajak yang terutang setiap tahunnya sesuai dengan ketentuan Undang-Undang Perpajakan yang berlaku.

b. Self Assessment System

Merupakan sistem pemungutan pajak yang memberikan kewenangan Wajib Pajak untuk menentukan sendilri jumlah pajak yang terutang setiap tahunnya sesuai dengan ketentuan Undang-Undang yang berlaku. Dalam hal ininisiatif dan kegiatan mengitung serta pelaksanaan pemungutan pajak berada ditangan Wajib Pajak.

c. With Holding System

Merupakan sistem pemungutan pajak yang memberikan wewenang kepada pihak ketiga yang ditunjukan untuk menentukan besarnya pajak yang terutang oleh wajib pajak sesuai dengan ketentuan Undang-Undang Perpajakan yang berlaku. 


\section{Sistem Self Assessment}

Dasar hukum pemungutan pajak di Indonesia adalah Pasal 23A Undang-Undang Dasar 1945, bahwa:"Pajak dan pungutan lain yang bersifat memaksa untuk keperluan negara diatur dengan undang-undang." Ini merupakan dasar filosofi pemungutan pajak, karena tidak ada perpindahan kekayaan tanpa persetujuan pemilik, menunjukkan bahwa masyarakat (pemilik) memberikan izin atas perpindahan sebagian kekayaannya kepada negara melalui proses pembuatan undang-undang. Bahkan di negara Inggris terdapat dalil pajak, No Taxation without Representation. (Dyah Adriantini Sintha Dewi *), Suharso *) dan Budiharto *)Volume XXIV No.1, Agustus Tahun 2012 hal 74) Self assessment system sebagai sistem penetapan pajak di Indonesia telah diterapkan sejak tax reform tahun 1983, setelah sebelumnya pernah diberlakukan official assessment system. Self assessment system merupakan sistem pemungutan pajak yang memberi kepercayaan, tanggung jawab kepada Wajib Pajak untuk menghitung, memperhitungkan, membayar dan melaporkan sendiri besarnya pajak yang harus dibayar. Official assessment system merupakan sistem pemungutan pajak yang memberi wewenang kepada Fiskus untuk menentukan besarnya pajak terutang. ( Marihot P S, 2010, hal. 184)

\section{Pengertian Wajib Pajak}

Istilah wajib pajak (disingkat WP) dalam perpajakan Indonesia merupakan istilah yang sangat popular. Istilah ini secara umum bias diartikan sebagai orang atau badan yang dikenakan kewajiban pajak. Dalam Undang-undang KUP lama, istilah wajib pajak didefinisikan sebagai orang pribadi atau badan yang menurut ketentuan peraturan perundang-undangan perpajakan ditentukan untuk melakukan kewajiban perpajakan, termasuk pemungutan pajak atau pemotongan pajak tertentu.

\section{Pajak Pertambahan Nilai}

Dilihat dari sejarahnya, Pajak Pertambahan Nilai merupakan pengganti dari Pajak Penjualan. Alasan dari penggantian ini karena Pajak Penjualan dirasa sudah tidak lagi memadai untuk menampung kegiatan masyarakat dan belum mencapai sasaran kebutuhan pembangunan, antara lain untuk meningkatkan penerimaan negara, mendorong ekspor, dan pemerataan pembebanan pajak (Mardiasmo, 2011).

\section{Pajak Penjualan Atas Barang Mewah}

Dasar hukum Pengenaan Pajak Penjualan Atas Barang Mewah adalah Undang-Undang Nomor 8 tahun 1983 tentang Pajak Pertambahan Nilai barang dan jasa dan Pajak Penjualan atas Barang Mewah sebagaimana telah beberapa kali diubah terakhir dengan Undang-Undang No 42 tahun 2009.

\section{Subjek Pajak Pertambahan Nilai (PPN) dan Pajak Penjualan Atas Barang Mewah (PPnBM)}

Subjek Pajak Pertambahan Nilai (PPN) dan Pajak Penjualan atas Barang Mewah (PPnBM) dikelompokkan menjadi dua yaitu Pengusaha Kena Pajak (PKP) dan Bukan (Non) Pengusaha kena Pajak.

a. Pengusaha Kena Pajak (PKP)

Pengusaha adalah orang pribadi atau badan dalam kegiatan usaha atau pekerjaannya menghasilkan barang, mengimpor barang, mengekspor barang, melakukan usaha perdagangan, memnfaatkan barang tidak berwujud dari luar Daerah Pabean, melakukan usaha jasa, atau melakukan usaha atau memanfaatkan jasa dari luar Daerah Pabean.

b. Bukan (Non) Pengusaha Kena Pajak (BPKP)

Yang dimaksud dengan Bukan Pengusaha Kena Pajak tetapi memiliki status sebagai subjek pajak adalah orang atau badan yang melakukan kegiatan yang dikenakan pajak, namun oleh Undang-undang tidak diklasifikasikan sebagai Pengusaha Kena Pajak. Ketentuan tersebut dimaksudkan adanya kemungkinan Pengusaha kecil yang ingin menjadi Pengusaha Kena Pajak. 


\section{Objek Pajak Pertambahan Nilai (PPN) dan Pajak Penjualan Atas Barang Mewah (PPnBM)}

\section{Objek Pajak Pertambahan Nilai (PPN)}

Objek Pajak Pertambahan Nilai (PPN) diatur dalam Undang-undang No.18 Tahun 2000 tercantum dalam Pasal 4, Pasal 16C dan pasal 16D yaitu sebagai berikut:

- Undang-undang No.18 Tahun 2000 Pasal 4 :

1) Penyerahan BKP didalam Daerah Pabean yang dilakukan oleh Pengusaha Kena Pajak. Syarat-syaratnya adalah :

a. Barang berwujud yang diserahkan merupakan Barang Kena Pajak adalh baran yang menurut sifatnya dapat berupa baramg bergerak ataupun barang tidak bergerak.

b. Barang tidak terwujud yang diserahkan merupakan Barang Kena Pajak tidak terwujud adalah adanya kegiatan penyerahan atas Barang Kena pajak tidak terwujud yang dilakukan oleh Pengusaha kecil.

c. Penyerahan dilakukan didalam Daerah Pabean adalah penyerahan atas Barang Kena Pajak yang dilakukan didalam wilayah Republik Indonesia yang meliputi wilayah darat, perairan dan ruang udara diatasnya serta tempat-tempat tertentu di Zona Ekonomi Eksklusif dan landas Kontinent yang didalamnya berlaku UU No.10 Tahun 1995 tentang kepabeanan.

d. Penyerahan dilakukan dalam rangka kegiatan usaha atau pekerjaannya adala setiap kegiatan penyerahan atas Barang Kena Pajak dalam rangka adanya perjanjian kegiatan usaha antara 2 (dua) pihak.

2) Impor Barang Kena Pajak adalah adanya suatu kegiatan penyerahan memasukkan Barang kena Pajak ke dalam Daerah Pabean dikenakan pajak yang dilakukan pemungutan pajak melalui Direktorat Jendral Bea dan Cukai.

3) Penyerahan Jasa Kena Pajak yang dilakukan didalam Daerah Pabean oleh Pengusaha Kena Pajak. Syaratsyaratnya adalah :

a. Jasa yang diserahkan merupakam Jasa Kena Pajak adalah setiap kegiatan pelayanan berdasarkan suatu perikatan atau perbuatan hokum yang menyebabkan suatu barang atau fasilitas atau kemudahan atau hak tersedia untuk dipakai, termasuk jasa yang dilakukan untuk menghasilkan barang karena pesanan atau permintaan dengan bahan dan atas petunjuk dari pemesan dikenakan pajak berdasarkan Undang-undang yang berlaku.

b. Penyerahan dilakukan di dalam Daerah Pabean adalah setiap kegiatan penyerahan jasa yang dilakukan dalam wilayah Republik Indonesia yang meliputi wilayah darat, perairan, dan ruang udara diatasnya serta tempat tertentu di Zona Ekonomi Eksklusif dan Landasan Kontinen yang didalamnya berlaku UU No.10 Tahun 1995 tentang kepabean.

c. Penyerahan dilakukan dalam rangka kegiatan usaha atau pekerjaannya adalah penyerahan jasa dalam perikatan perjanjian antara 2 (dua) pihak yang melakukan kegiatan usaha.

4) Pemanfaatan Barang Kena Pajak tidak berwujud dari luar Daerah Pabean didalam Daerah Pabean adalah Barang Kena Pajak tidak berwujud yang dimanfaatkan oleh Nilai (PPN), contohnya yaitu Pengusaha A yang berkedudukan di Jakarta memperoleh hak menggunakan merek yang dimiliki Pengusaha B yang berkedudukan di Hongkong. Atas pemanfaatan merek tersebut oleh Pengusaha A didalam Daerah Pabean terutang Pajak Pertambahan Nilai.

5) Pemanfaatan Jasa Kena Pajak dari Luar Pabean di dalam Daerah Pabean adalah jasa yang berasal dari luar Daerah Pabean yang dimanfaatkanoleh siapapun didalam Daerah Pabean dikenakan Pajak Pertambahan Nilai (PPN), contohnya Pengusaha Kena Pajak C di Surabaya memanfaatkan Jasa Kena Pajak dari Pengusaha B yang berkedudukan di Singapura. Atas pemanfaatan Jasa Kena Pajak tersebut terutang Pajak Pertambahn Nilai (PPN).

6) Ekspor Barang Kena Pajak oleh Pengusaha Kena Pajak adalah Pengusaha yang melakukan ekspor barang Kena Pajak hanya Pengusaha yang telah dikukuhkan menjadi Pengusaha Kena Pajak.

- Undang-undang No. 18 Tahun 2000 pasal 16C : Pajak Pertambahan Nilai (PPN) dikenakan atas kegiatan membangun sendiri yang dilakukan tidak dalam kegiatan usaha atau pekerjaan oleh orang pribadi atau badan yang hasilnya digunakan sendiri atau digunakan pihak lain yang batasannya dan tata caranya diatur dengan Keputusan menteri keuangan. 
- Undang-undang No.18 Tahun 2000 pasal 16D : Pajak Pertambahan Nilai (PPN) dikenakan atas penyerahan aktiva oleh Pengusaha kena Pajak yang menurut tujuan semula aktiva tersebut tidak untuk diperjualbelikan, sepanjang Pajak Pertambahan Nilai yang dibayar pada saat perolehannya dapat dikreditkan.

\section{Objek Pajak Penjualan atas Barang Mewah (PPnBM)}

Objek Pajak Penjualan atas Barang Mewah diatur Undang-undang No.18 Tahun 2000 tercantum dalam pasal 5 yaitu sebagai berikut :

1) Pengenaan Pajak Penjualan atas Barang Mewah terhadap :

a. Penyerahan Barang Kena Pajak Yang Tergolong Mewah yang dilakukan oleh pengusaha yang menghasilkan Barang Kena Pajak Yang Tergolong Mewah tersebut didalam daerah pabean dalam kegiatan usaha atau pekerjaannya.

b. Impor Barang kena Pajak Yang Tergolong Mewah.

2) Pajak Penjualan atas Barang Mewah dikenakan hanya satu kali pada waktu penyerahan Barang Kena Pajak yang Tergolong Mewah oleh pengusaha yang menghasilkan atau pada Perhitungan Dasar waktu impor.

\section{Tarif dan Cara Perhitungan Dasar Pengenaan PPN dan PPnBM}

\section{Tarif dan Cara Perhitungan Dasar Pengenaan PPN}

Tarif Pajak Pertambahan Nilai (PPN) tercantum dalam Undang-undang No.42 Tahun 2009 Pasal 7 adalah:

- Tarif Pajak Pertambahan Nilai adalah 10\% (sepuluh persen).Tarif Pajak Pertambahan Nilai (PPN) Barang Kena Pajak dan Jasa Kena Pajak merupakan tari tunggal yang dikenakan untuk semua jenis Barang Kena Pajak dan Jasa Kena Pajak.

- Tarif Pajak Pertambahan Nilai atas eksport Barang Kena Pajak adalah 0\% (nol persen).Tarif Pajak Pertambahan Nilai sebesar 0\% (nol persen) dikenakan atas ekspor Barang Kena Pajak untuk mendorong para pengusaha mampu menghasilkan barang ekspor sehingga dapat bersaing dipasar luar negeri. Penerapan tarif Pajak Pertambahan Nilai 0\% (nol persen) bukan berarti pembebasan dari pengenaan PPN, melainkan agar Pajak Masukan yang telah dibayar oleh pengusaha pada saat pembelian barang eksport tersebut dapat dikreditkan.Dengan Peraturan Pemerintah, tarif pajak dapat diubah serendah-rendahnya 5\% (lima persen) dan setinggi-tingginya $15 \%$ (lima belas persen).

\footnotetext{
2. Tarif dan Cara Perhitungan dasar Pengenaan Pajak Penjualan Barang Mewah (PPnBM)

Tarif PPN dan PPnBM

1. Tarif PPN adalah $10 \%$ (sepuluh persen).

2. Tarif PPN sebesar 0\% (sepuluh persen) diterapkan atas:

- ekspor Barang Kena Pajak (BKP) Berwujud;

- ekspor BKP Tidak Berwujud; dan

- ekspor Jasa Kena Pajak.

3. Tarif PPnBM adalah paling rendah $10 \%$ (sepuluh persen) dan paling tinggi $200 \%$ (dua ratus persen).

4. Tarif PPnBM atas ekspor BKP yang tergolong mewah adalah 0\% (nol persen).
}

\section{METODE PENELITIAN}

\section{Jenis Penelitian}

Data kuantitatif adalah data yang dapat diukur dalam skala numerik (angka) yang dapat dibedakan menjadi dua yaitu data interval dan data rasio. Dalam penelitian ini data kuantitatif yang dibutuhkan adalah laporan jumlah wajib pajak di Kantor Pelayanan Pajak Pratama di Kota Manado.

\section{Sumber Data}

Sumber data yang digunakan dalam penelitian ini, yaitu data primer merupakan data yang diperoleh secara langsung dari perusahaan atau instansi melalui hasil pengamatan dan wawancara karyawan bagian 
pengolaan data dan informasi perusahaan atau instansi tersebut. Perusahaan atau instansi objek penelitian terkait tersebut adalah Kantor Pelayanan Pajak Pratama Kota Manado.

\section{Prosedur Penelitian}

Prosedur penelitian yang dilakukan adalah sebagai berikut :

1. Melakukan kunjungan langsung pada objek penelitian.

2. Melakukan wawancara dengan Kantor Pelayanan Pajak Pratama di Kota Manado.

3. Mengumpulkan data-data yang diperlukan yang berhubungan dengan penelitian untuk menjadi dasar acuan dalam penelitian.

4. Mengolah data-data yang sesuai dengan dasar teori yang akan digunakan dalam penelitian.

\section{Metode Pengumpulan Data}

1. Survei pendahuluan

Hal ini dilakukan untuk mengetahui kedaaan dari perusahaan secara keseluruhan sehingga dapat menentukan masalah apa yang dihadapi UD. Yusni.

2. Survei lapangan

Suvei dilakukan dengan cara:

a. Interview, yaitu mengadakan wawancara dalam hal ini Tanya jawab dengan pimpinan dan staf yang ditujukan untuk mengadakan penelitian terhadap tata cara pelaporan yang menyangkut masalah tersebut.

b. Documenter, cara pengumpulan data dengan menggunakan arsip dan dokumen-dokumen dari perusahaan yang bersangkutan.

3. Studi kepustakaan

Hal ini dimaksudkan untuk memperoleh landasan teori yang berhubungan dengan permasalahan melalui interview yang ada, yang akan digunakan sebagai pembahasan masalah.

\section{Metode Analisis Data}

Data yang telah diolah kemudian dianalisis dengan menggunakan analisis deskriptif kualitatif. Analisis deskriptif kualitatif adalah analisis yang diwujudkan dengan cara menggambarkan kenyataan atau keadaan atau suatu obyek dalam bentuk uraian kalimat berdasarkan keterangan-keterangan dari pihak-pihak yang berhubungan langsung dengan penelitian ini. Hasil analisis tersebut kemudian di interpretasikan guna memberikan gambaran yang jelas terhadap permasalahan yang diajukan.(Tarigan,2013)

\section{HASIL PENELITIAN DAN PEMBAHASAN}

\section{Sejarah Singkat Kantor Pelayanan Pajak Pratama Manado}

Kantor Pelayanan Pajak Pratama Manado merupakan instansi vertikal Direktoral Jendral Pajak dibawah Kantor wilayah DJP Sulawesi Bagian Utara, Tengah, Gorontalo dan Maluku Utara yang bernaung di bawah Departemen Keuangan Republik Indonesia. Tugas dari Kantor Pelayanan Pajak Pratama Manado adalah melaksanakan tugas pokok Direktorat Jendral Pajak dalam penerimaan negara.Pengolahan yang berasal dari pajak ini meliputi administrasi penerimaan Pajak Negara.

Pada tahun 1989 pemerintah menetapkan penggantian nama kantor inspeksi pajak kembali menjadi Kantor Pelayanan Pajak (KPP). Dengan demikian berubah pula nama Kantor Inspeksi Pajak Manado menjadi KPP Manado hingga sekarang kemudian dengan adanya pertumbuhan ekonomi dan meningkatnya jumlah wajib pajak yang potensial diwilayah Sulawesi Utara dan Sulawesi Tengah maka pada tahun 1989 Kantor Pelayanan 
Pajak Manado oleh Kantor Pusat dibagi menjadi empat wilayah kerja yaitu Kantor Pelayanan Pajak Manado, Kantor Pelayanan Pajak Gorontalo, Kantor Pelayanan Pajak Palu, dan Kantor Pelayanan Pajak Luwuk.

Dengan adanya remunerasi di lingkungan Direktorat Jendral Pajak, maka terhitung mulai tanggal 01 Desember 2008 untuk kantor wilayah DJP Sulawesi Utara, Tengah, Gorontalo, dan Maluku dibagi menjadi sebelas kantor Pelayanan Pajak Pratama dan tujuhbelas Kantor Penyuluhan dan Konsultasi Perpajakan. Dan untuk Kantor Pelyanan Pajak Manado dirubah menjadi Kantor Pelayanan Pajak Pratama Manado. Dengan demikian berkurang pula wilayah administrasi dan wilayah kerja Kantor Pelayanan Pajak Pratama Manado.

\section{Hasil Penelitian}

Analisis efektivitas adalah pengukuran dalam arti tercapainya sasaran atau tujuan yang telah ditentukan sebelumnya. Jelas bila sasaran atau tujuan telah tercapai sesuai dengan yang direncanakan sebelumnya, hal ini dikatakan efektif. Jadi apabila tujuan atau sasaran tidak sesuai dengan yang ditentukan, maka pekerjaan itu kurang efektif.

Analisis yang digunakan untuk mengetahui apakah pemungutan PPnBM di KPP Pratama Manado berdasarkan ketetapan PPnBM apakah efektif atau kurang efektif adalah:

$$
\text { Efektivitas }=\frac{\text { Penerimaan } P P n B M}{\text { Target } P P n B M} \times 100 \%
$$

Pada dasarnya semua pekerjaan yang akan dikerjakan supaya menuai hasil sesuai dengan yang diharapkan tidak terlepas dari perencanaan yang matang dan sesuai dengan kriteria yang telah ditetapkan serta sesuai dengan manajemen yang digariskan oleh pakar ekonomi.Data laporan realisasi penerimaan pajak di KPP Pratama Manado dalam 4 (empat) tahun terakhir, yaitu tahun 2011-2014 dapat dilihat pada tabel 1 berikut : 
Tabel 1

Realisasi Penerimaan pajak di KPP Pratama Manado Tahun 2011-2014

\begin{tabular}{|c|c|c|c|c|}
\hline \multirow[t]{2}{*}{ JENIS PAJAK } & \multicolumn{4}{|c|}{ REALISASI PENERIMAAN } \\
\hline & 2011 & 2012 & 2013 & 2014 \\
\hline A. PPh Non Migas & 554.974.501.435 & 645.102.217.359 & 710.399 .521 .750 & 794.478.989.086 \\
\hline 1. PPh Pasal 21 & 221.962 .013 .393 & 239.582 .624 .685 & 250.617 .314 .680 & 304.034 .331 .779 \\
\hline 2. PPh Pasal 22 & 13.363 .347 .613 & 16.016 .266 .214 & 17.868.386.884 & 14.458 .266 .023 \\
\hline 3. PPh Pasal 22 Impor & 1.925 .574 .159 & 1.051 .763 .896 & 1.949 .492 .657 & 2.001 .980 .765 \\
\hline 4. PPh Pasal 23 & 61.018 .760 .473 & 69.759.777.921 & 81.746.297.657 & 54.095 .187 .623 \\
\hline 5. PPh Pasal 25/29 OP & 17.238.287.577 & 20.863.236.192 & 18.193 .899 .758 & 17.514 .175 .030 \\
\hline 6. PPh Pasal 25/29 Badan & 97.377.475.211 & 112.464 .459 .644 & 157.050.787.128 & 142.158 .524 .224 \\
\hline 7. PPh Pasal 26 & 1.750 .477 .856 & 8.783 .521 .419 & 2.662 .625 .050 & 1.287 .081 .253 \\
\hline 8. PPh Pasal Final & 140.334 .108 .585 & 176.568 .829 .325 & 180.258.617.192 & 258.848 .201 .560 \\
\hline 9. PPh Non Migas Lainnya & 4.456 .568 & 9.572 .520 & 49.597 .926 & 491.250 \\
\hline 10. PPh Fiskal Luar Negeri & & 2.165 .543 & 2.802 .818 & 53.749 .579 \\
\hline B. PPN dan PPnBM & 384.917 .872 .261 & 519.735.274.945 & 565.167 .720 .265 & 559.802 .433 .360 \\
\hline 1. PPN Dalam Negeri & 378.654 .817 .560 & 514.854 .396 .390 & 562.514 .370 .863 & 555.055 .529 .026 \\
\hline 2. PPN Impor & 5.213 .902 .264 & 2.725 .085 .282 & 2.303 .454 .773 & 2.960 .741 .880 \\
\hline 3. PPN Lainnya & 1.000 .986 .135 & 13.388 .958 & 38.053 .329 & 9.844 .791 \\
\hline 4. PPnBM dalam Negeri & 29.392 .824 & 2.121.410.359 & 303.557 .866 & 1.767 .832 .378 \\
\hline 5. PPnBM Impor & 18.773 .478 & 14.756 .092 & 8.283 .434 & 8.485 .285 \\
\hline 6. PPnBM Lainnya & & 6.237 .864 & & \\
\hline C. PBB & 22.896.723.537 & 33.281.555.485 & 32.673.029.748 & 6.153.675.382 \\
\hline E. Pajak Lainnya & 22.841.984.098 & 26.988.623.592 & 28.827.641.610 & 29.951.514.414 \\
\hline 1. Bea Materai & 988.050 .000 & 1.225 .825 .000 & 1.332 .612 .000 & 1.523 .304 .000 \\
\hline 2. Penjualan Benda Materai & 21.853.500.000 & 24.565 .500 .000 & 27.432.900.000 & 28.356.087.000 \\
\hline 3. Bunga Penagihan PPh & 434.098 & 181.621 .775 & 16.163 .030 & 56.576 .638 \\
\hline 4. Bunga Penagihan PPN & & 1.015 .676 .517 & 45.966 .580 & 15.546 .776 \\
\hline \multicolumn{5}{|l|}{ 5. Bunga Penagihan PTLL } \\
\hline F. PPh Migas & 31.539.131 & 35.706 .971 & 156.462 .745 & 12.593 .055 \\
\hline TOTAL & 985.662 .620 .462 & 1.225.143.378.352 & 1.337.224.676.118 & 1.390.399.205.297 \\
\hline
\end{tabular}

Sumber: KPP Pratama Manado

Pada tabel 1 dapat dilihat PPN dan PPnBM sangat mempengaruhi tingkat penerimaan pajak di KKP Pratama Manado. Penerimaan Pajak dapat dilihat juga data tersebut menunjukan adanya peningkatan penerimaan pajak setiap tahunnya kecuali pada tahun 2014.

Data laporan target dan realisasi Penerimaan PPnBM di KPP Pratama Manado dalam 4 (empat) tahun terakhir, 2011 - 2014 dapat dilihat pada tabel 4.2 sebagai berikut : 
Tabel 2

Target dan Realisasi Penerimaan PPnBM di KPP Pratama Manado Tahun 2011-2014

\begin{tabular}{lcc}
\hline Tahun & $\begin{array}{c}\text { Target } \\
\text { Penerimaan }\end{array}$ & $\begin{array}{c}\text { Realisasi } \\
\text { Penerimaan }\end{array}$ \\
\hline 2011 & 828.240 .676 & 29.392 .824 \\
\hline 2012 & 34.616 .429 & 2.121 .410 .359 \\
\hline 2013 & 1.640 .348 .000 & 303.557 .866 \\
\hline 2014 & 1.586 .118 .000 & 1.765 .905 .106 \\
\hline Jumlah & $\mathbf{4 . 0 8 9 . 3 2 3 . 1 0 5}$ & $\mathbf{4 . 2 2 0 . 2 6 6 . 1 5 5}$ \\
\hline
\end{tabular}

Sumber : KPP Pratama Manado

Pada tabel 2 dapat dilihat PPnBM sangat mempengaruhi tingkat penerimaan pajak di KPP Pratama Manado. Data diatas mengalami peningkatan pada tahun 2012 dan tahun 2014.

\section{Pembahasan}

Analisis perhitungan tingkat efektivitas penerimaan PPnBM berdasarkan target di KPP Pratama Manado Tahun 2011-2014 tentunya mempunyai dasar untuk menentukan target dalam penerimaan PPnBM di KPP Pratama. Sebelum kita masuk dalam pembahasan disini terlebih dahulu akan dijelaskan mengenai dasar penentuan target penerimaan pajak PPnBM. Informasi yang didapat dari KPP Pratama Manado memberitahukan bahwa penjelasan mengenai dasar penetapan target penerimaan $\mathrm{PPnBm}$ itu senditri didasari atas kebijakan pemerintah yang diatur oleh DPR tapi pada tahun sebelumnya dasar penentuan target PPnBM KPP Pratama Manado didasari oleh teori. Dan pada tahun ini untuk dasar penentuan target penerimaan PPnBM di KPP Pratama Manado didasari ketentuan kebijakan dari pemerintah.

Dan untuk penerimaan PPnBM KPP Pratama Manado yang saya terima dalam 4 tahun terakhir 20112014 itu didasari sesuai kebijakan pemerintah dalam target nasional ditentukan sebesar 10\% ditambah penerimaan tahun sebelumnya. Tapi kita harus ketahui bersama bahwa 10\% tersebut itu bisa saja berubah nilainya itu dikarenakan setelah diturunkan ke kanwil disetiap daerah tidak sama nilainya $10 \%$ tapi pada akhir perhitungan untuk semua kanwil di tiap daerah digabungkan mencapai $10 \%$ sesuai target nasional. Jadi intinya pada tiap kanwil persentasenya berbeda dalam hal penentuan target penerimaan.Dan untuk penentuan dasar target penerimaan PPnBM KPP Manado dapat dapat dari realisasi tahun sebelumnya ditambah persentase (\%) kanwil.

Efektivitas atau hasil guna pajak itu, mengukur hubungan antara hasil pungut suatu pajak dan potensi hasil pajak itu, dengan anggapan semua wajib pajak membayar pajak masing-masing, dan membayar seluruh pajak terhutang masing-masing, dan pengukuran efektivitas pemungutan Pajak Penjualan atas Barang Mewah menggunakan Perhitungan sebagai berikut:

Efektivitas $=\frac{\text { Realisasi Penerimaan } P P n B M \text { yang dipungut }}{\text { Target penerimaan } P P n B M} \times 100 \%$

Untuk tahun 2011, dengan Realisasi PPnBM sebesar Rp.29.392.824, dan target PPnBM sebesar Rp.828.240.676, maka efektivitas pemungutannya diketahui dari perhitungan sebagai berikut:

Efektivitas 2011 $=\frac{R p \cdot 29 \cdot 392.824}{R p \cdot 828 \cdot 240.676} \times 100 \%=35,55 \%$ 
Dari perhitungan diatas diketahui bahwa pada tahun 2011, pemungutan Efektivitas Pajak Penjualan atas Barang Mewah sebesar 35,55\%.

Untuk tahun 2012, dengan realisasi PPnBM sebesar Rp.2.121.410.359, dan target PPnBM sebesar Rp.34.616.429, maka efektivitas pemungutannya diketahui sebagai berikut:

Efektivitas Tahun $2012=\frac{R p \cdot 2 \cdot 121.410 .359}{R \text { p. } 34.616 .429} \times 100 \%=612,84 \%$

Dari perhitungan diatas diketahui bahwa pada tahun 2012, pemungutan Efektivitas Pajak Penjualan atas Barang Mewah sebesar 612,84\%.

Untuk tahun 2013, dengan realisasi PPnBM sebesar Rp.303.557.866, dan target PPnBM sebesar Rp.1.640.348.000, maka efektivitas pemungutannya diketahui sebagai berikut:

Efektivitas Tahun $2013=\frac{R p \cdot 303.557 .866}{R p \cdot 1 \cdot 640.348 .000} \times 100 \%=18,50 \%$

Dari perhitungan diatas diketahui bahwa pada tahun 2013, pemungutan Efektivitas Pajak Penjualan atas Barang Mewah sebesar 18,50\%.

Untuk tahun 2014, dengan realisasi PPnBM sebesar Rp.1.765.905.106, dan target PPnBM sebesar Rp.1.586.118.000, maka efektivitas pemungutanya diketahui sebagai berikut:

Efektivitas Tahun $2014=\frac{R p \cdot 1.765 .905 .106}{R p \cdot 1.586 .118 .000} \times 100 \%=111,33 \%$

Dari perhitungan diatas diketahui bahwa pada tahun 2014, pemungutan Efektivitas Pajak Penjualan atas Barang Mewah sebesar 111,33\%.

dapat dilihat peningkatan dari tahun 2011 sampai 2014 dimana terlihat efektivitas, dengan adanya kenaikan atau penurunan setiap tahunnya. Dari pegolahan data tersebut dapat diketahui tingkat keefektivan dari setiap tahunnya.

target pada tahun 2012 mengalami penurunan, dimana pada tahun 2011 sebesar Rp 828.240.676, sedangkan pada tahun 2012 hanya sebesar Rp 34.616.429 kemudian pada tahun $2013 \mathrm{Rp} 1.640 .348 .000$ dan pada tahun $2014 \mathrm{Rp}$ 1.586.118.000. Diantara empat tahun diatas pada tahun 2012 adalah tahun target yang paling rendah dibandingkan dengan tahun 2011, 2013, 2014. Namun dalam presentase tahun 2012 dinilai sangat Sangat Efektif/Efektif karena target yang diberikan terealisasi atau melibihi target yang diberikan. Hal tersebut yang mendukung penulis dapat mengatakan antara tahun 2011-2014 sangat efektif/efektif.

\section{KESIMPULAN}

Berdasarkan hasil penelitian dan pembahasan pada bab sebelumnya, maka dapat diambil kesimpulan sebagai berikut :

1. Target Penerimaan Pajak Penjualan atas Barang Mewah dalam kurun waktu empat tahun dari tahun 20112014 terus mengalami penigkatan kecuali pada tahun 2012. Namun, dari target yang diberikan KPP Pratama Manado sudah terealisasikan secara efektif. Pemungutan Pajak Penjualan atas Barang Mewah sekarang mengalami peningkatan. Namun, Pajak Penjualan atas Barang Mewah mengalami perubahan, berdasarkan sebagaimana telah diubah dengan Peraturan Pemerintah Nomor 22 Tahun 2014pemerintah menaikkan tarif Pajak Penjualan atas Barang Mewah (PPnBM) mulai 19 April 2014.Kementerian Perdagangan mendukung adanya kenaikan Pajak Penjualan atas Barang Mewah (PPnBM) untuk mengurangi jumlah mobil mewah. Beberapa perusahaan otomotif merencanakan menginvestasikan dananya ke Indonesia sebab Indonesia merupakan pasar yang besar. Nantinya, PPnBM mobil mewah ini akan dinaikkan dari $75 \%$ menjadi $125 \%$. Penerbitan Peraturan Pemerintah (PP) birokrasinya memang rumit, karena harus melewati pengecekan dari 
beberapa kementerian yang terkait dengan aturan tersebut. Untuk PPnBM, harus melalui Kementerian Perindustrian, Kementerian Hukum dan HAM, dan Sekretariat Negara (Setneg).

2. Pajak Penjualan atas Barang Mewah di KPP Pratama Manado dinilai sudah efektif karena presentasenya diatas $90 \%$. Akan tetapi jika pemungutanya atau target yang diberikan terealisasi dengan baik, PPnBM pemungutanya termasuk dalam kategori.

\section{Saran}

Berdasarkan penelitian yang dilakukan pada Kantor Pelayanan Pajak Pratama Manado maka saran yang dapat diberikan antara lain sebagai berikut :

1. Diharapkan lebih menigkatkan target dan realisasi pajak Penjualan atas Barang Mewah, dan lebih mengotrol wajib pajak agar mengurangi tingkat kecurangan wajib pajak, sehingga hal tersebut Penerimaan Pajak Penjualan atas Barang Mewah dapat terealisasi secara sangat efektif dan pastinya akan berpengaruh terhadap penerimaan pajak.

2. Tatacara pembayaran sudah bagus, jadi harus tetap dipertahankan dan lebih ditingkatkan kedisiplinan dalam hal penyetoran atau pembayaran pajak.

3. Dengan patuhnya Wajib Pajak membayar pajak, sehingga penerimaan negara akan lebih meningkat dan terlebih itu akan mendukun pembangunan di negara maupun di dalam daerah-daerah. Karena hal tersebut dapat memberikan nilai manfaat secara merata dan masa yang akan datang lebih bernilai tinggi terhadap masyarakat.

\section{DAFTAR PUSTAKA}

Liputan 6, April 2014."Daftar Tarif Baru Pajak Mobil Mewah Berlaku 19 April 2014", http://bisnis.liputan6.com.

Mardiasmo, 2011.Perpajakan, Edisi Revisi, Penerbit Andi, Yogyakarta. , 2008.Perpajakan, Edisi Revisi, Penerbit Andi, Yogyakarta.

Marihot Pahala Siahaan, 2010.Hukum Pajak Elementer, Graha Ilmu, Yogyakarta.

\section{Sumber Lain:}

Peraturan Pemerintah Indonesia Nomor 41 Tahun 2013, tentang Pajak Penjualan Atas Barang Mewah.

Peraturan Pemerintah Indonesia Nomor 22 Tahun 2014, tentang Pajak Penjualan Atas Barang Mewah Kendaraan Bermotor.

Undang-Undang Republik Indonesia Nomor 16 Tahun 2000, KUHPerdata tentang Perpajakan.

Undang-Undang Republik Indonesia Nomor 28 Tahun 2007, tentang Tata Cara Perpajakan.

Undang-Undang Republik Indonesia Nomor 42 Tahun 2009, tentang Pajak Penjualan Atas Barang Mewah.

$\underline{\text { www.duniapajak.com }}$

$\underline{\text { www.google.co.id }}$

www.pajak.go.id 
